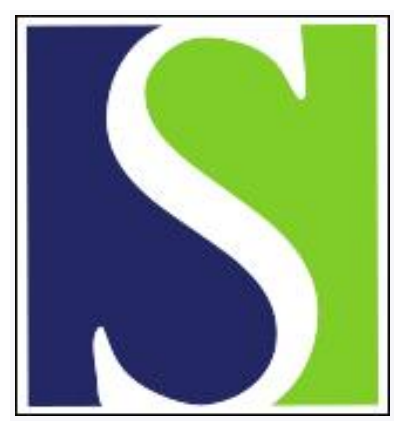

Scand J Work Environ Health 1999;25(3):227-232

https://doi.org/10.5271/sjweh.428

Issue date: Jun 1999

Ozone-induced respiratory illness during the repair of a portland cement kiln

by Sanderson WT, Almaguer D, Kirk LH III

The following article refers to this text: 2002;28(2):117-123

Key terms: electrostatic precipitator; eye irritation; kiln maintenance; ozone; respiratory irritation; sic 3241 (portland cement manufacturing)

This article in PubMed: www.ncbi.nlm.nih.gov/pubmed/10450773

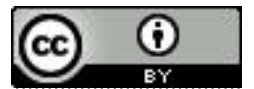




\title{
Ozone-induced respiratory illness during the repair of a portland cement kiln
}

\author{
by Wayne T Sanderson, PhD, ${ }^{1}$ Daniel Almaguer, MS, ${ }^{1}$ L Harvey Kirk III, MS ${ }^{2}$
}

\author{
Sanderson WT, Almaguer D, Kirk LH III. Ozone-induced respiratory illness during the repair of a portland cement \\ kiln. Scand J Work Environ Health 1999;25(3):227-232.
}

\begin{abstract}
Objectives Workers at a portland cement plant had experienced acute respiratory and eye irritation when performing maintenance inside a kiln. These episodes were associated with a bleach-like odor, which was only reported during maintenance operations. An industrial hygiene investigation was conducted to determine the cause of the illness.

Methods While workers replaced refractory brick inside the kiln, air samples were collected for chlorine, sulfur dioxide, inorganic acid, ozone, and dust. After the rebricking was completed and all the workers had exited the kiln, its electrostatic precipitator was reduced to half power and the induced-draft (ID) fan was turned off to recreate conditions present during illness episodes.

Results Chlorine, inorganic acid, and ozone were not detected, and only trace concentrations of sulfur dioxide were detected while workers were inside the kiln. However, when conditions present during previous episodes were recreated, the bleach-like odor was soon evident. Chlorine was not detected, but 0.09 to $0.11 \mathrm{ppm}$ of ozone was measured at the discharge end of the kiln, and $4.5 \mathrm{ppm}$ was measured at the inlet end. Within a half hour after the electrostatic precipitator was turned off and the ID fan was turned on, the ozone concentrations decreased to background levels of $0.02-0.03 \mathrm{ppm}$.

Conclusions Somewhat lower ozone exposures may have occurred during previous kiln maintenance operations due to more open access portals, but previous episodes of eye and respiratory irritation were probably caused when ozone, generated by the electrostatic precipitator, back-drafted into the kiln after the ID fan was turned off.
\end{abstract}

Key terms electrostatic precipitator, eye irritation, kiln maintenance, ozone, respiratory irritation, SIC 3241 (portland cement manufacturing).

The National Institute for Occupational Safety and Health (NIOSH) received a request from the management of a portland cement plant to evaluate a bleach-like odor inside a kiln. The odor had only been noticeable in March 1993 and February 1996, when this particular kiln was shut down for maintenance. Workers inside the kiln reported acute respiratory and eye irritation associated with the odor. The kiln operates continuously throughout the year, and no odor or health hazard had been reported during normal kiln operations. Therefore, an industrial hygiene evaluation was conducted from 3 to 5 December 1996 while the kiln was shut down for repair. This report describes the results of that investigation.

The original cement plant, which was built in 1910 , was completely modernized in 1939 and again in 1957. The second modernization more than tripled the size of the plant, and three of the kilns built at this time (kilns
$1-3)$ were operating at the time of the investigation. In 1970 , during a third modernization, a fourth kiln was constructed (kiln 4) that increased the production capacity of the plant to $900000 \mathrm{t}$ /year. The bleach-like odor and complaints of respiratory irritation had only been associated with the fourth kiln.

\section{Portland cement manufacturing process}

Portland cement is produced by heating oxides of calcium, silicon, aluminum, and iron in various combinations to a temperature of $2700^{\circ} \mathrm{F}\left(1482.2^{\circ} \mathrm{C}\right)$ in a rotating kiln to form calcium silicates, calcium aluminates, and calcium aluminoferrites (1). The principal raw materials for manufacturing portland cement are limestone, shale,

1 Division of Surveillance, Hazard Evaluations, and Field Studies, National Institute for Occupational Safety and Health, Cincinnati, Ohio, United States.

2 Lehigh Portland Cement Company, 117 South Main Street, Union Bridge, Maryland, United States.

Reprint requests to: Dr Wayne T Sanderson, Division of Surveillance, Hazard Evaluations, and Field Studies, National Institute for Occupational Safety and Health, 4676 Columbia Parkway, Cincinnati, OH 45226, USA. [E-mail: wts1@cdc.gov] 
sand, and recycled iron slag, which provide the calcium, aluminum, silicon, and iron sources. No chlorine-containing compounds are used in the process.

Several methods are used for manufacturing portland cement. The process used at this plant is the long, dry kiln process in which raw materials are mixed, ground, and conveyed into a kiln as a dry powder. The four rotary kilns are basically three-fourths to one inch (1.91-2.54 $\mathrm{cm})$ thick, welded-steel tubes, 11.5 feet $(3.51 \mathrm{~m})$ in diameter and 400 feet $(121.92 \mathrm{~m})$ in length, lined with high-temperature refractory bricks 6 to 9 inches $(15.24$ $-22.86 \mathrm{~cm})$ thick. No mortars, binders, or coatings are used on the bricks. Cement kilns rotate on a slightly inclined axis with the raw materials entering the kilns at the upper end (back end or inlet end). The materials are heated to progressively higher temperatures until they leave the lower end of the kiln (discharge end or front end) as calcium silicate clinkers. The clinkers are mixed with varying amounts of gypsum (hydrated calcium sulfate) to control the hardening rate and ground into a fine powder to produce the finished product.

At this plant, pulverized coal was the primary fuel, with scrap tires used as a supplemental fuel. Pulverized coal was blown into the discharge end of the kilns, while tires were fed by an automated system into the middle of the kilns, one tire per revolution. The practice of burning scrap tires began during the summer of 1995. At one time, waste oils from refineries were also used as a supplemental fuel, but this practice was stopped in 1994.

For dust pollution control, induced-draft (ID) fans drew waste gases from the kilns through electrostatic precipitators to remove dust particles. The remaining gases were then vented out exhaust stacks. The 3 kilns which began operation in 1957 shared a common dust control system and exhaust stack, but kiln 4, which began operation in 1970, had a separate dust control system and exhaust stack. In 1995, the height of the exhaust stacks was increased due to excessive, in-plant sulfur dioxide exposures from the combustion of coal in the kilns. Since that time no further problems with excessive sulfur dioxide exposure have been reported. Figure 1 shows the exhaust stack and electrostatic precipitators at the inlet end of kiln number 4.

\section{First occurrence of acute respiratory illness}

The first occurrence of respiratory problems associated with the repair of kiln 4 was in March 1993. Nine workers were replacing refractory bricks approximately 20 to 30 feet $(6.10-9.14 \mathrm{~m})$ from the discharge end of the kiln; 6 workers were inside the kiln, 2 of whom were laying bricks in the bottom of the kiln, and 3 workers were working outside the kiln. The ID fan had been turned off at 0500 because the night crew, which had been replacing bricks, complained the air draft made them cold; the electrostatic precipitator continued to operate. The nine dayshift workers began replacing bricks at 0700, and 20 minutes later one of the workers who was laying bricks in the bottom of the kiln developed a severe cough, headache, profuse perspiration, nausea, and fatigue. The worker reported a chlorine or bleach-like odor inside the kiln. Other workers reported that they smelled the same odor on the worker's clothes. The sick worker was taken to a hospital for evaluation; he had a history of asthma and was given a bronchial dialator. His symptoms soon dissipated, and he returned to work the following day.

The 5 other workers who were inside the kiln also noticed the chlorine-like odor and complained of coughing, headaches, sore throats, and shortness of breath, but

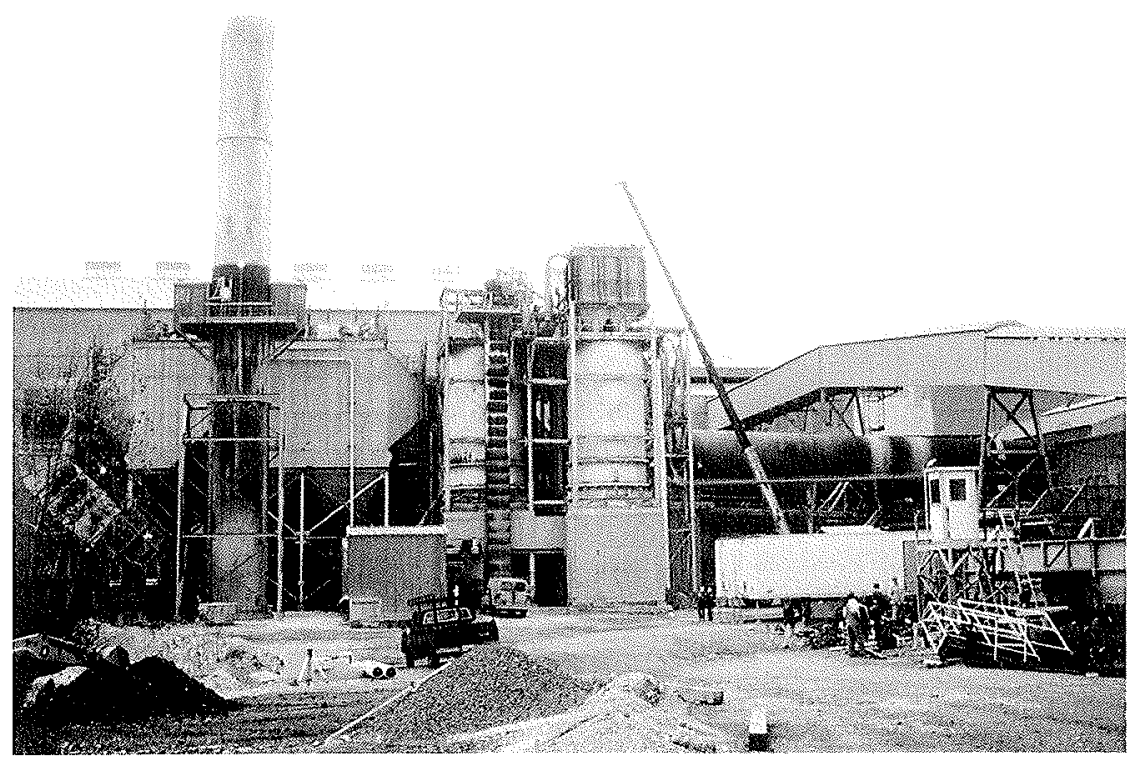

Figure 1. Back end of kiln number 4 showing exhaust stack and electrostatic precipitators. 
their symptoms were less severe and did not require medical treatment. The 3 workers who were working outside the kiln noticed the bleach-odor but did not experience any symptoms. Soon after the ID fan was restarted, the chlorine-like odor was gone, and the workers completed the rebricking operation.

\section{Second occurrence of acute respiratory illness}

The second occurrence of respiratory problems associated with the repair of kiln 4 was in February 1996. The kiln was shut down when the kiln-feed hopper at the inlet-end of the kiln became clogged with wet raw materials. Seven hours later, 2 workers entered the inlet end of the kiln and started to remove the clogged material. These workers left the plant 4 hours later and did not report any odor or respiratory symptoms. However later that same afternoon, 2 replacement workers reported a chlorine-like odor immediately upon entering the kiln. A 3rd worker joined the 2 replacement workers at 1930 . At the end of their workshift (2100), all 3 workers reported a bleachlike odor and symptoms of cough, chest tightness, and burning eyes. Subsequently, no one entered the kiln until 4 third-shift workers entered 2.5 hours later. Within minutes, all of these workers reported a strong chlorine odor and symptoms of cough, chest tightness, nausea, and burning eyes and nose.

It is not certain at what time the ID fan was turned off, but it was not operating at 2330 when the 4 workers entered the kiln. The electrostatic precipitator was operating at half power. Fresh air was limited to what came through the rear kiln-access door; however, when the ID fan was restarted, conditions inside the kiln became so dusty the workers lost visibility. The four workers left the kiln for 15 minutes to allow the fan to remove the odor. The fan was then turned off again, and the workers reentered the kiln. The odor and the workers' symptoms quickly returned. All the workers then exited the kiln, and the unclogging operation was completed by workers standing outside the kiln. All 7 workers who had experienced symptoms continued to complain of residual chest tightness and eye irritation the following day. However, none of them sought medical attention and within 2 days their symptoms were gone.

\section{Suspected cause of the respiratory illness}

The acute, short-term symptoms experienced by the workers during these two maintenance operations suggested they were exposed to an irritant gas or dust. Although the workers reported a chlorine or bleach-like odor, the raw materials for clinker production do not contain chlorine compounds, and chlorine is not used in any aspect of kiln operations (1). However, sulfur dioxide, which is a common by-product of coal combustion, causes eye and upper respiratory irritation (2). In addition, ozone, which is formed from high electrical voltage discharge in electrostatic precipitators, causes irritation of the eyes and mucous membranes (3). It was suspected that residual concentrations of these gases back-drafted from the kiln exhaust system into the kiln while it was shut down for maintenance. Portland cement dust can cause dermatitis and may be irritating to the eyes and nose due to its alkaline, hygroscopic, and abrasive properties (3). Neither acute episodes of respiratory irritation nor a chlorine odor has been reported in association with portland cement dust, but portland cement workers have reported dyspnea more frequently than referents (4). Therefore, it was thought that short-term exposures to high concentrations of kiln dust may have caused the chest tightness and shortness of breath.

Since no outbreaks of respiratory irritation had occurred while kiln 4 was operating or during other maintenance operations, something must have been different during the maintenance operations in March 1993 and February 1996. Therefore, the purpose of the study was to investigate workers' exposures to irritant gases and dust during a kiln maintenance operation and to measure concentrations while attempting to recreate the conditions under which the workers had experienced symptoms previously.

\section{Methods}

Air samples for irritant gases and dust were collected during the first shut down of kiln 4 for maintenance after the February 1996 episode. In December 1996, the kiln was shut down for replacement of refractory bricks in the first 25 feet $(7.62 \mathrm{~m})$ of the discharge end of the kiln. The other 3 kilns continued to operate during this maintenance operation. When the kiln was cool enough, workers removed the coating of hard, fused-rock material and old refractory bricks from the interior of the kiln. After the removal operation, repair crews started rebricking. When the repair was complete and all workers had exited the kiln, additional dust and gas samples were collected in the middle and in the inlet end of the kiln under re-created conditions similar to those in which workers had previously experienced respiratory symptoms the ID fan was turned off and the electrostatic precipitators were operated at half power. During this experiment workers were not inside the kiln.

Area samples were collected for chlorine, inorganic acid, sulfur dioxide, respirable, and total dust by attaching sampling media to tripods positioned near the front, middle, and rear of the kiln (figure 2) (5). Short-term samples for ozone were collected frequently at various locations inside the kiln, using direct-reading color indicator tubes and a Metrosonic Toxic Gas Monitor ${ }^{\mathrm{TM}} \mathrm{di}$ rect-reading monitor. Since a bleach-like odor had been 


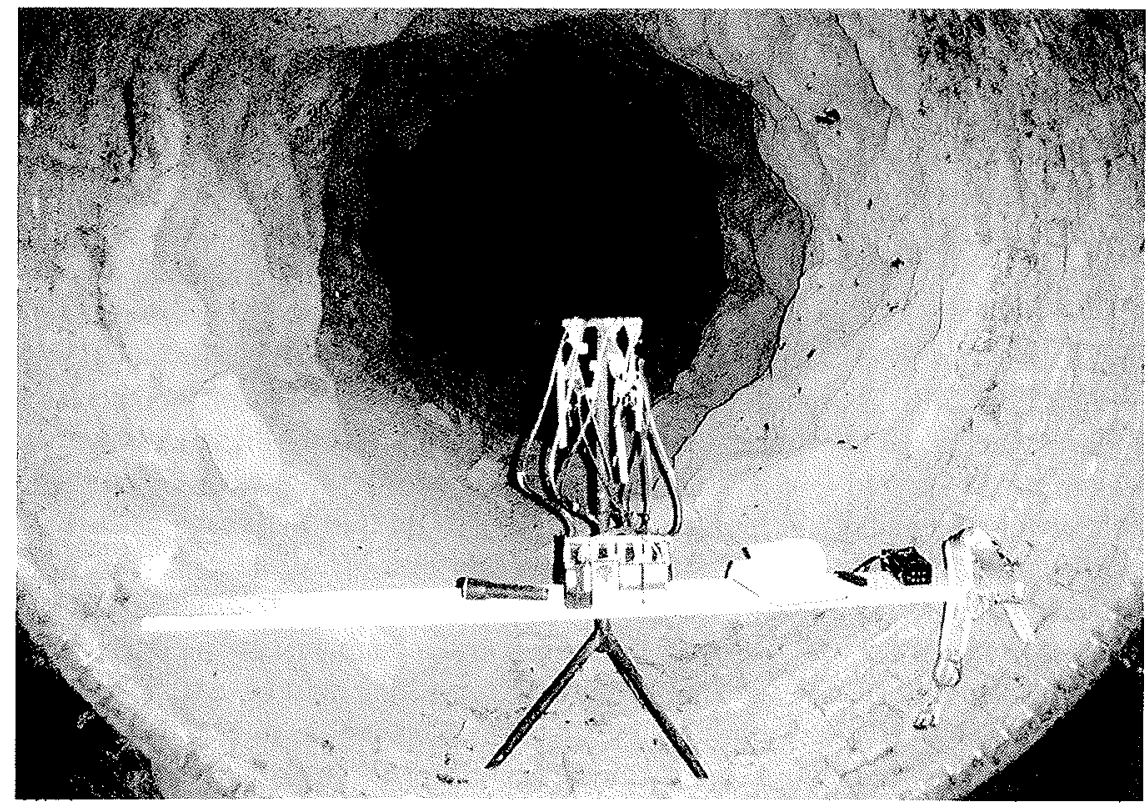

Figure 2. Area sampling station inside the front end of kiln number 4. reported during earlier outbreaks, samples for chlorine (chlorides) were collected to measure the presence of chlorine (5). Inorganic acids were not suspected of being present during kiln operation or maintenance, but samples were taken for them to evaluate chlorine acid vapors as a potential cause of worker symptoms. The respirable dust samples were analyzed for crystalline silica to evaluate workers' potential risk for silicosis (6), and the total dust samples were analyzed for arsenic, cadmium, copper, total chromium, magnesium, nickel, and zinc content since these metals have been documented as affecting the respiratory system (7). Personal-breathingzone samples were collected for chlorine, sulfur dioxide, and respirable and total dust by attaching sampling media to the collars of workers involved in the rebricking operation.

\section{Results}

The respirable and total dust exposures were considerably higher while workers were removing coating and bricks from the kiln than when they were during rebricking; however, none of the dust measurements exceeded current exposure criteria (8). Quartz and cristobalite were not detected in any of the respirable dust samples, and none of the metal concentrations detected in the total dust samples exceeded current exposure criteria (8).

Chlorine and inorganic acids were not detected in any air samples, and only trace quantities of sulfur dioxide were detected in one area sample, collected at the inlet end of the kiln $(0.007 \mathrm{ppm})$. Ozone was not detectable using either direct-reading color indicator tubes or the
Metrosonic Toxic Gas Monitor ${ }^{\mathrm{TM}}$ direct-reading monitor at any location while workers were inside the kiln.

In less than 1 hour after the sampling equipment was placed inside kiln 4 and conditions in which workers had previously become ill were recreated, a faint bleach-like odor was reported near the front of the kiln. Within 3 hours after the ID fan had been turned off and the electrostatic precipitators reduced to half-strength, chlorine and ozone measurements were collected at the discharge end of the kiln and through a portal at the inlet end. No chlorine was detected. However, 0.6 to $0.7 \mathrm{ppm}$ of ozone was measured on 2 ozone color indicator tubes and 0.09 to $0.11 \mathrm{ppm}$ of ozone was measured using the Metrosonic $^{\text {TM }}$ monitor. At the inlet end, 2 pump strokes on an ozone indicator tube saturated the tube, indicating that the ozone concentrations inside the kiln were well above $0.7 \mathrm{ppm}$. (The ozone color indicator tube was designed to measure ozone concentrations between 0.05 and 0.7 ppm with $\pm 25 \%$ accuracy using 10 strokes of a handheld bellows air pump.) The Metrosonic ${ }^{\mathrm{TM}}$ direct-reading meter showed a stable ozone concentration of 4.5 ppm. The hands and shirt sleeves of the investigator who took the measurements through the portal had a strong, pungent chlorine or bleach-like odor. Several workers stated that the odor on the investigator's hands and clothing was the same odor they had smelled during the 2 previous respiratory irritation episodes.

Background readings collected with the Metrosonic ${ }^{\mathrm{TM}}$ monitor in the plant yard were 0.02 to $0.03 \mathrm{ppm}$ of ozone. Ten minutes after the electrostatic precipitator was turned off and the ID fan was turned back on, the ozone concentration measured using the Metrosonic ${ }^{\text {TM }}$ direct-reading meter dropped to $0.17 \mathrm{ppm}$. Within 30 minutes, the Metrosonic ${ }^{\mathrm{TM}}$ meter readings were at background levels. 
A summary of the ozone measurements is presented in table 1 .

\section{Concluding remarks}

The air sampling measurements collected during a kiln repair operation at the portland cement plant suggest that previous occurrences of eye and upper respiratory irritation were caused by ozone exposure and not chlorine compounds or other irritant dusts or gases. The source of the ozone was the electrostatic precipitator. When the kiln ID exhaust fan was turned off while the precipitator continued to operate, ozone back-drafted from the precipitator into the kiln. The ozone concentration measured during the investigation at the inlet end of the kiln approached $5 \mathrm{ppm}$, a value well above existing exposure criteria. However, this measurement was collected with the door into the back of the kiln closed, so the ozone concentration was probably higher than that experienced by the workers attempting to unclog the kiln feed hopper in February 1996 when the door was open.

No complaints of a chlorine-like odor or respiratory illness were reported in association with maintenance on the 3 older kilns because they shared a common electrostatic precipitator and exhaust system. Since the ID fan must continue to operate for the 2 other kilns while the $3 \mathrm{rd}$ is being repaired, ozone is prevented from back-drafting from the electrostatic precipitator.

Electrostatic precipitators are commonly used in portland cement plants, electricity generation plants, and smelters, for example, to remove particulates from exhaust air. They typically consist of discharge electrodes at high negative potential hanging between rows of electrically grounded collecting electrodes (9). The high potential difference between these electrodes creates a corona discharge causing gas ions to attach to particles in the air stream flowing between the electrodes. The electric field through which these charged particles flow forces them onto the collecting electrodes. The particles then give up their charge and are removed by mechanical agitation. Workers are potentially exposed to ozone generated by the high voltage discharge whenever they are associated with airflow through the precipitators.

Ozone possesses a characteristic pungent odor which can be detected at 0.02 to $0.05 \mathrm{ppm}$ (10). Ozone is used as a disinfectant for air and water; for bleaching textiles, oils, and waxes; and in organic syntheses. It is also produced in welding arcs and corona discharges and by ultraviolet radiation. Ozone is a potent irritant to the eyes and mucous membranes of the respiratory tract (10). Symptoms following acute excess exposure to ozone include nose and throat irritation, coughing, dyspnea, chest pain and tightness, burning eyes, headache, and severe fatigue. Pulmonary edema may occur, sometimes several hours after exposure has ceased. The toxic effects of ozone can be attributed to its strong oxidative capacity.
Specifically, ozone can act by initiating peroxidation of polyunsaturated fatty acid present in the cell membrane or by direct oxidation of amino acids and proteins also found in the membranes. If damage is severe, the cell dies; necrosis is commonly reported in the lungs of heavily exposed animals. In animal studies, a characteristic ozone lesion occurs at the junction of the conducting airways and the gas-exchange region of the lung following acute exposure. This anatomical site is probably affected in humans as well (11).

The NIOSH recommended exposure limit (REL) for ozone is $0.1 \mathrm{ppm}$, to be measured as a $15-$ minute ceiling concentration (8). NIOSH has also recommended an immediately dangerous to life or health limit (IDLH) of 10 ppm for ozone (8). The current permissible exposure limit (PEL) recommended by the Occupational Safety and Health Administration for ozone is $0.1 \mathrm{ppm}$ as an 8 -hour time-weighted average and $0.3 \mathrm{ppm}$ as a $15-$ minute ceiling concentration (8). The ozone concentrations inside the kiln during previous maintenance operations may have approached $5 \mathrm{ppm}$, but the actual ozone concentrations that workers encountered are unknown.

Sulfur dioxide was only detected in trace concentrations and was unlikely to have contributed to the irritation outbreaks. The airborne dust levels, quartz, and metal concentrations did not indicate that workers were at increased risk for pneumoconiosis (silicosis) or other significant pulmonary effects. However, by wearing respirators while working inside a kiln, employees can reduce exposure to dust particles that may dry and irritate their nasal passages. The irritation outbreaks were not temporally associated with the burning of used tires or waste

Table 1. Summary of the ozone measurements. (ID $=$ induceddraft, $N A=$ not available, $N D=$ not detected)

\begin{tabular}{|c|c|c|c|}
\hline Location and operation & ID $\tan$ & $\begin{array}{l}\text { Electrostatic } \\
\text { precipitator }\end{array}$ & $\begin{array}{c}\text { Ozone } \\
\text { concentration } \\
\text { (ppm) }\end{array}$ \\
\hline \multicolumn{4}{|l|}{ Plant yard - background } \\
\hline Color indicator tube & NA & NA & ND \\
\hline Metrosonic meter & NA & NA & $0.02-0.03$ \\
\hline \multicolumn{4}{|c|}{$\begin{array}{l}\text { Inside discharge end of kiln } \\
\text { - workers replacing kiln bricks }\end{array}$} \\
\hline Color indicator tube & on & Off & ND \\
\hline Metrosonic meter & On & Off & 0.03 \\
\hline \multicolumn{4}{|c|}{$\begin{array}{l}\text { Inside inlet end of kiln } \\
\text { - workers replacing kiln bricks }\end{array}$} \\
\hline Color indicator tube & On & Off & ND \\
\hline Metrosonic meter & On & Off & 0.03 \\
\hline \multicolumn{4}{|c|}{$\begin{array}{l}\text { Just outside discharge end of } \\
\text { kiln - no workers inside kiln }\end{array}$} \\
\hline Color indicator tube & Off & On & $0.6-0.7$ \\
\hline Metrosonic meter & Off & On & $0.09-0.11$ \\
\hline \multicolumn{4}{|c|}{$\begin{array}{l}\text { Through portal in infet end of } \\
\text { kiln - no workers inside kiln }\end{array}$} \\
\hline Color indicator tube & Off & On & $>0.7$ \\
\hline Metrosonic meter & Off & On & 4.5 \\
\hline
\end{tabular}


oils. Chlorine was not detected at any of the air sampling locations and is not used in the production of portland cement; therefore the distinctive chlorine-like odor and the irritation symptoms experienced by workers on previous occasions were caused by ozone back-drafting into the kiln from the electrostatic precipitator when the precipitator was operating at half power and the ID fan was turned off.

Before workers enter a portland cement kiln or any other industrial processing equipment in which particle emissions are controlled by electrostatic precipitators, the precipitators should be turned off and the ID fans should continue to operate. If the ID fans must be turned off, precipitators should remain off, and fans should be run for several minutes to remove residual ozone before workers enter the kiln. While workers are inside kilns, ozone levels should be monitored, and, if ozone is detected, the workers should exit the kiln and the source of the ozone should be investigated. Workers should be warned of the symptoms of excessive exposure to ozone, and, if they begin to experience these symptoms, they should exit the kiln area and report their symptoms to their supervisor and plant health and safety staff.

\section{Acknowledgments}

The authors wish to acknowledge the assistance of James Harris and the employees of the Lehigh Portland Cement Company. We are also grateful to Mark Boeniger, Eric Esswein, Steven Lenhart, and Elizabeth Ward for their review of this manuscript. We are especially grateful to Stephen Minshall for his insight and counsel during this investigation.

Mention of company or product names in this report does not constitute endorsement by the National Insti- tute for Occupational Safety and Health (NIOSH), Centers for Disease Control and Prevention (CDC).

\section{References}

1. Shreve R, Brink J. Chemical process industries. New York (NY): McGraw-Hill Book Company, 1977:156-66.

2. Clayton G, Clayton F, editors. Patty's industrial hygiene and toxicology; vol II Part A. 4th edition. New York (NY): John Wiley and Sons, 1993:807-11.

3. Hathaway G, Proctor N, Hughes J. Proctor and Hughes' chemical hazards of the workplace. 4th edition. New York (NY): Van Nostrand Reinhold, 1996:486-7, 528-9.

4. Abrons H, Petersen M, Sanderson W, Engelberg A, Harber P. Symptoms, ventilatory function, and environmental exposures in portland cement workers. Br J Ind Med 1988;45:368 - 75.

5. National Institute for Occupational Safety and Health (NIOSH). NIOSH manual of analytical methods (NMAM). 4th edition. Cincinnati (OH): NIOSH, 1994. DHHS (NIOSH) publication no $94-113$.

6. Abrons H, Petersen M, Sanderson W, Engelberg A, Harber P. Chest radiography in portland cement workers. J Occup Environ Med 1997:39:1047-54.

7. Goyer R. Toxic effects of metals. In: Amdur M, Doull J, Klaassen C, editors. Casarett and Doull's toxicology. 4th edition. New York(NY): Pergamon Press, 1991:623-80.

8. National Institute for Occupational Safety and Health (NIOSH). NIOSH pocket guide to chemical hazards. Cincinnati (OH): NIOSH, 1997. DHHS (NIOSH) publication no 97140.

9. Considine D, Considine G, editors. Van Nostrand's scientific encyclopedia. 7th edition. New York (NY): Van Nostrand Reinhold, 1989.

10. Beard R. Inorganic compounds of oxygen, nitrogen, and carbon. In: Clayton G, Clayton R, editors. Patty's industrial hygiene and toxicology; vol 2C. 2nd edition. New York (NY): John Wiley \& Sons, 1982:4067-94.

11. Lippman M. Health effects of ozone: a critical review. J Air Pol Control Assoc 1989;39:672-95.

Received for publication: 17 June 1998 